\title{
Die betekenis van Jesus en Sy koninkryk vir die kerk
}

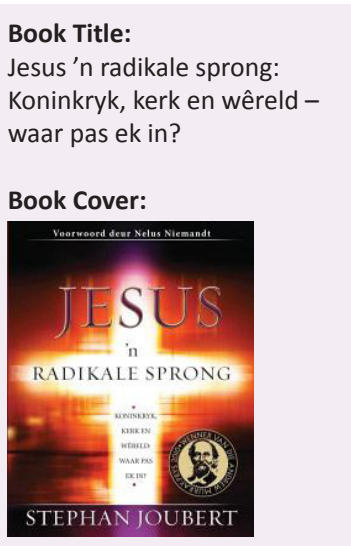

Author:

S. Joubert

ISBN:

978-1-77000-842-7

Publisher:

Christelike Uitgewers-

maatskappy, 2007, R99.95

*Book price at time of review

-

Review title:

Die betekenis van Jesus en Sy koninkryk vir die kerk

\section{Reviewer:}

Ferdi P. Kruger ${ }^{1}$

\section{Affiliation:}

${ }^{1}$ Reformed Church

Meyerspark, South Africa

Email:

ferdikruger4@gmail.com

Postal address:

PO Box 75973, Lynnwoodrif,

Pretoria 0040, South Africa

How to cite this book review: Kruger, F.P., 2013, 'Die

betekenis van Jesus en Sy koninkryk vir die kerk', In die Skriflig/In Luce Verbi 47(1), Art. \#131, 2 pages. http://dx.doi.org/10.4102/ ids.v47i1.131

Read online:
Navorsing fokus tans op die kerk wat in veranderende tye moet verander. Dit is duidelik dat die landskap van millennium drie vinnig verander. Oor die wyse waarop die kerk moet verander, word dikwels geredeneer. Die saak waarmee elke gelowige worstel, is die vraag na die kontoere wat die Woord bied. Die skrywer van hierdie boek, Stephan Joubert, skryf onderhoudend oor die ewige en vasstaande Woord van God in 'n veranderende tyd; 'n tyd waarin die stem van Christene ongelukkig al hoe stiller word. Die skrywer beskryf hierdie toestand van sake in die kerk - die kerk wat soms nie veel van die wêreld wil weet nie - aan die hand van 'n metafoor, naamlik 'n geestelike lughawe waar gelowiges soos reisigers wag op hulle vlug na die hemel.

Waaroor handel hierdie boek? Die sentrale argument van die boek is eintlik 'n gebed dat die kerk, as navolgers van Christus, anders (radikaal) moet begin dink en anders moet begin leef. Die uitdaging vir die kerk is om dit wat hulle in Christus is en dit wat hulle van Hom in kerkwees ontvang, te gaan leef. Dit moet hulle doen deur uit te reik na die wêreld rondom hulle. Die kerk moet leer begryp dat hierdie uitreik na die wêreld niks anders is as God se eintlike bedoeling vir die kerk nie. Die boek bestaan uit agt hoofstukke wat goed georden en logies saamgevoeg is om die gesprek oor die ekklesiologie te dien. In hoofstuk 1 word die gelaatstrekke van millennium drie beskryf. Die gevaar van die gietvorms van kerklike gebruike en 'n starre godsdiens word hierin beskryf. Die invloed van informasie-oorbelading is ' $n$ baie insiggewende faktor wat na die oppervlak gebring word. Al die veranderings bring negatiewe persepsies mee wat weer ' $n$ kritiese ingesteldheid teenoor die kerk voortbring. In hoofstuk 2 word, met deeglike eksegetiese kommentaar, op die uniekheid en vreemdheid van Jesus se bediening op aarde gewys. Hierdie optrede van Jesus vereis 'n ommekeer in gelowiges se lewens. In hoofstuk 3 word 'n uiteensetting van Jesus as 'n liminale figuur gebied. Jesus was bewus van die oorgang wat op die kerk van alle eeue gewag het en dat die kerk op die breuklyn van die oorgang van die ou na die nuwe bedeling gestaan het. Die belangrike rol wat verhoudings in Jesus se optrede gespeel het, word benadruk. In hoofstuk 4 word beskryf in watter mate die koms van Jesus se koninkryk vir baie mense vreemd was. Hierdie uniekheid van God se koninkryk word deeglik begrond deur eksegetiese lyne te trek.

In hoofstuk 5 word die implikasie van die eerste vier hoofstukke gestel, naamlik dat die siening van God se koninkryk meebring dat die bestaande siening van kerkwees ook noodwendig hierby moet aanpas. In hierdie hoofstuk word 'n belangrike saak gestel, naamlik dat die kerk nie gelyk aan die ampte (dienste) is nie en dat die wese van die kerk op 'n bybelse wyse verstaan moet word. Hierin moet die diens van gelowiges groter klem ontvang. In hoofstuk 6 neem die skrywer die leser terug na die eerste volgelinge van Jesus. By hierdie navolgers was 'n lewensverbintenis teenoor Jesus die kardinale saak. In hulle lewens het hulle geloof geskitter in en deur hulle verhoudings. In hoofstuk 7 fokus die skrywer op die kerk van môre en die koninkryk van God. Die skrywer pleit daarvoor dat die boodskap van die Reformasie deurgetrek moet word, sodat gelowiges voetsoolvlak-navolgers van Christus sal word waarin 'n missionale lewenswyse die magneet sal wees. Volgens Joubert het die kerk wel 'n toekoms indien gelowiges op 'n bybelse wyse kreatief begin dink en doen. Hoofstuk 8 bied 'n bondige en sterk slot waarin die navolging van Christus bepleit word.

Die boek is in 'n populêr-wetenskaplike styl geskryf. Die waarde van die boek lê ongetwyfeld in Joubert se deeglike verklaring van die Skrif met gedeë eksegese van kardinale begrippe soos kerk, bekering, volgeling, koninkryk en koinonia vergesel van goeie navorsing oor die praksis van hedendaagse kerke in millennium drie. Dit word alles met 'n selfstandige opinie opgevolg.

Die boek is sodanig geskryf dat teoloë en gelowiges wat graag dieper wil lees, dit kan begryp. In die teologiese wêreld, maar ook in plaaslike gemeentes behoort almal wat by die kerk in veranderende tye belang het, van hierdie boek kennis te neem. Die boek kan daarom van harte

Copyright: (C) 2013. The Authors. Licensee: AOSIS OpenJournals. This work is licensed under the Creative Commons Attribution License. 
vir predikante aanbeveel word, maar ook vir gemeentes wat erns maak met die bediening in veranderende tye. Hierdie boek, wat van goeie taalgebruik getuig, kan handig vir toerustingsgeleenthede gebruik word en dit kan selfs vir Bybelstudiegroepe van waarde wees.

Die uitgebreide bronnelys is baie nuttig en verhoog die wetenskaplike waarde van die boek. Dit sou baie moeilik wees om punte van kritiek uit te lig. Die boek is beslis nie vir blote kennisname geskryf nie. Die onderwerp wat beredeneer word, is so omvangryk dat 'n profetiese besinning hieroor geensins ontydig is nie. Lesers word gedwing om self met ' $n$ oop Bybel en met ' $n$ bewustheid van wat rondom hulle gebeur, die boek te lees. Die skrywer het sy veld baie deeglik verken en het daarin geslaag om die doelwit wat hy aan die begin gestel het, te bereik en goed te belig. Om fyner punte van kritiek te bedink, is om op 'n selektiewe en subjektiewe wyse met so 'n belangrike boek om te gaan. Hierdie resensent kan hierdie boek van harte aanbeveel en is oortuig daarvan dat dit veel waarde tot die lesers se verwysingsraamwerk sal toevoeg. 